\title{
Gençlerin Büyükşehir Belediye Hizmet Algısı ve Beklentileri (Örnek Bir Uygulama)
}

\author{
DOI: $10.26466 /$ opus.393544
}

\author{
Mehmet Colak* İmam Yapıc1** - Neslihan Çolak ***- Tahsin Çetin **** \\ ${ }^{*}$ Doç. Dr., Muğla Sıtkı Koçman Üniversitesi, Teknoloji Fakültesi, Muğla / Türkiye \\ E-Posta: cmehmet@mu.edu.tr \\ ORCID: 0000-0003-4780-587X \\ ** Bilim Uzm., Muğla Sıtkı Koçman Üniversitesi, Teknoloji Fakültesi, Muğla / Türkiye \\ E-Posta: imamyapici@mu.edu.tr \\ ORCID: 0000-0002-0723-9845 \\ *** Öğr. Gör., Muğla Sıtkı Koçman Üniversitesi, Muğla Meslek Yüksekokulu, Muğla / Türkiye \\ E-Posta: ncolak@mu.edu.tr \\ ORCID: 0000-0003-1275-4283 \\ ***** Araş. Gör., Muğla Sıtkı Koçman Üniversitesi, Teknoloji Fakültesi, Menteşe / Muğla / Türkiye \\ E-Posta: tahsincetin@mu.edu.tr \\ ORCID: $\underline{0000-0002-7886-981 X}$ \\ Öz
}

Büyükşehir Belediyeleri bulunduklarn yerlerdeki bireylere yerel yönetim olarak hizmet sunma konusunda yönetsel birimler olarak görev almaktadırlar. Belediyelerin birey beklentilerini iyi irdelemesi ve bu beklentilere göre hizmet sunması gerekmektedir. Beklentiler doğrultusunda hizmet kalitesi bireyden bireye farklılık göstermektedir. Beklentileri kişinin sahip olduğu eğitim seviyesi, gelir durumu ve sosyal düzeyi gibi pek çok değiş̧en etkilemektedir. Bu çalışmanın konusu gençlerin Büyükşehir Belediyelerinin sağladığg hizmetleri nasıl algıladığ ve Büyükşehir Belediyelerinden beklentilerini oluşturmaktadır. Bu çalışmada dünyada her alanda yaşanan hızlı gelişmelerin etkisiyle Türkiye'de gençlerde artan beklentileri büyükşehir belediyelerinin ne derece karşıladığı ölçülmüştür. Beklentilerin hem küresel ölçekte hem de yerel ölçekte artması ve değiş̧en devlet/kamu-yurttaş ilişkisinin belediyeler üzerinde pozitif bir etki oluşturduğu bir gerçektir. Buradaki katılımclların ekonomik ve demografik özelliklerine göre belediyelerden memnuniyette farklılıklara rastlanmaktadır. Ne var ki, tam anlamıyla Weberyen bürokratik örgütlenmeden kurtulamayan belediyelerin örgüt yapısının artan beklentileri karşılamada hem örgütlenme olarak hem de anlayış olarak yetersiz kaldığı bulgularımız arasındadır. Bu anlamda, büyüßşshir belediyelerinin daha yenilikçi bir örgüt yapısına ve faaliyetlere ihtiyacı olduğu sonuç ve öngörülerimiz arasındadır.

Anahtar Kelimeler: Birey Algısı, Genç Kuşak, Hizmet, Kültür Faaliyetleri, Yerel Yönetim, İnovasyon. 


\title{
Youth's Impressions of and Expectations from the Services of Metropolitan Municipalities (A Sample Application)
}

\begin{abstract}
Metropolitan Municipalities are assigned as administrative units which serve as local authorities to individuals of where they reside. Municipalities should examine the individual expectations well and serve according to them. The quality of service in accordance with expectations change by the person. A lot of variables alter expectations such as the level of education, financial state and social situation. The subject of this study is how the youth perceive the services provided by Metropolitan Municipalities and what they expect. How well Metropolitan Municipalities can meet the expectations of youth which increased upon the rapid developments in every area throughout the World is measured in the study. It is a fact that the expectations increased both locally and universally and the changing relationship between state/public and the citizen has a positive effect on municipalities. Differences were found among participants on how well they are satisfied with the municipality according to their financial and demographic features. However, we observe that the organization structures of municipalities held back by the Weberian organization remain insufficient to meet the increasing expectations in both their organizations and their perceptions. Therefore, we predict and conclude that Metropolitan Municipalities need more innovative organizational structures and activities.
\end{abstract}

Anahtar Kelimeler: Individual Perception, Young Generation, Service, Cultural Activities, Local Government, Innovation. 


\section{Giriş}

Küreselleşen dünyada iletişim ve ulaşım araçlarının hızlı bir şekilde gelişmesi hem mobilizasyonu arttırmış hem de bireylerin taleplerinin şartlarla birlikte çeşitlenmesine sebebiyet vermiştir. Özellikle teknolojik gelişmelerle daha yakından alakalı olan gençlerde bu durum daha görünür olmuş ve gençlerin beklentileri artmıştır. Farklılaşan ve artan taleplere karşı bunları karşılamaya yönelik yerel yönetim ve organizasyonlar geliştirilmiştir. Bunlardan biri de büyükşehir belediyeleridir. Özellikle Türkiye'de üniversitelerin ülke sathına yayılması/dağılması, sayısının artması ülkenin eğitim seviyesini artırmakla birlikte söz konusu o illerin idari yönetimlerine sorumluluklar yüklemiştir. Bu sorumlulukların en önemlilerinden biri üniversite kurulmasından sonra o illere genç akışının başlaması ve o gençlerin talepleri konusunda oluşmaktadır. Üniversitelerin kurulması, üniversitelerin kurulduğu ilin genç nüfusunu önemli miktarda artırmakta ve geliştirmektedir. Buna bağlı olarak gençlerin oranının artması; gençlerin sosyo-kültürel etkinlikler, ulaşım, barınma, eğlence, spor ve sanat gibi kamu hizmet taleplerinin ortaya çıkmasına neden olmaktadır. Genel olarak yerelde bu gibi kamu hizmeti sağlayıcıları belediyeler ile Büyükşehir belediyeleri, sivil toplum kuruluşları ve özel kamu kuruluşları olarak karşımıza çıkmaktadır.

Türkiye'de yerel yönetimleri düzenleyen temel kanunlar yeniden ele alınarak günün şartlarına uygun, çağdaş yönetim ilkelerini esas alan, idari süreçlerde sivil katılıma önem veren bir yerel yönetim anlayışı hayata geçirilmek istenmiştir. Bu amaçla Büyükşehir Belediyesi başta olmak üzere İl Özel İdaresi ve Belediye Kanunları değiştirilmiş, bu alanlarda yeni kanunlar çıarılmıştır. Böylece hantal işleyen merkezi yönetimin bir takım yetkilerinin, yerel yönetimlere başka bir ifadeyle belediyelere aktarılması sağlanarak yerel yönetim birimleri olan belediyeler güçlendirilmiştir. Söz konusu yeni kanunların temel amaçlarından bir tanesi vatandaşların yaşam kalitesini ve vatandaş memnuniyetini artıran sorumluluğu alan bir belediye hizmeti anlayışını inşa etmektir. Yeni yerel yönetim anlayışı ile birlikte son yıllarda yaşam kalitesi, hizmet kalitesi ve vatandaş memnuniyeti kavramı, belediyeler açısından çok daha önemli birer kavram haline gelmiştir (İnce ve Şahin, 2014). 
Bu çalışmanın konusu büyükşehir belediyesi kapsamında yaşayan ve büyük kısmını gençlerin oluşturduğu; kamu hizmeti sağlayıcıları olan belediye ve büyükşehir belediye algısını ve bunlardan beklentilerini öğrenmek amacıyla yapılan ampirik bir uygulamadır. Bu çalışmanın genelde ve özelde olmak üzere iki amacı bulunmaktadır. Bu çalışmayla Türkiye'de yeni uygulamaya geçen büyükşehir belediye yönetimlerinin genel görüntüsünü ve genç vatandaşların yeni büyükşehir belediyelerinin yönetim ve organizasyon yeteneklerini büyükşehir belediyesi üzerinden açıklamaktadır. Bu çalışmanın diğer bir amacı ise Türkiye sathına yayılmış üniversite gençlerinin kamu hizmeti algısını ve beklentileri hakkında fikir sahibi olmak ve belediyelerin yönetim organizasyon bakımından kendilerini geliştirmesine, eksikliklerini görmesine ve yenilik yapmasına katkı sağlamaktır. Çalışmanın önemi olarak gençlerin memnuniyetlerini ve rahatsızlıklarını öğrenmek ve yeni kurulan büyükşehir belediyelerinin gençler üzerinde bıraktığı fayda ve sıkıntılar hakkında bir veri elde ederek ilgili kamu kurum ve kuruluşlarına yönlendirici teorik uygulamalı bir kaynak oluşturmakla birlikte gençlerin yerel yönetimlerden beklentilerini analiz etmektir.

\section{Kavramsal Çerçeve (Literatür)}

Bu bölümde çalışmanın daha açık şekilde anlaşılmasını sağlayacağını öngördüğ̈̈müz "Kamu Hizmeti “ kavramı ile teorik olarak bağlantılı olan objektif ve sübjektif kamu hizmeti çeşitleriyle yeni kamu hizmeti anlayışı kavramları açıklanmıştır. Daha sonrasında ise çalışmanın ana eksenini oluşturan kamu hizmetinin kalitesini belirten kriterler ortaya konmuştur. $\mathrm{Bu}$ kriterlerin ortaya konmasındaki amaç ise, kamu hizmeti alanların, kamu hizmeti sağlayan kamu kurum ve kuruluşlarının kalite derecelerini belirlemektir.

\section{Kamu Hizmeti Kavramı}

"Kamu Hizmeti" kavramı 19. Yüzyılın sonlarına doğru ortaya Batı'da yani Fransa'da ortaya çıkmaya ve kurumsallaşmaya başlamış ve daha sonrasında idare hukukunun en temel kavramlarından biri haline gelmiştir. Kavram, dünyadaki gelişimine ve önemine paralel olarak, Türk 
idare hukuku tarihinde de yerini almıştır. Kamu hizmeti kavramı, Osmanlı devletinden bugüne kadar gelinen süreçte önemli bir yer tutmuştur (Yılmaz, 2008). Kıta Avrupası ülkelerinde olduğu gibi Türkiye'de kamu hizmeti teori, rejim ve sistematiğini kabul ederken Fransa'dan çok etkilenmiştir. "Kamu Hizmeti” kavramı Fransızların "Service Public" tabirinden ilk olarak Türkçeye "Hidematı Umumiye" şeklinde çevrilmiş ve hukukumuzda kullanılmıştır. "Umumi" kelimesinin tam olarak "public" sıfatını karşılamamasından dolayı daha sonra "Hidematı amme veya "Amme Hizmeti" tabirleri kullanılmıştır. Türkçe'de kullanılan "Amme" kelimesinin de Fransızca da ki "Public" sıfatını tam olarak karşılamamış olması amme kelimesinin yerine daha uygun bir sözcük olan "kamusal" sözcügünün kullanılması ile birlikte "Kamusal hizmet" tabiri kullanılmaya başlanmıştır. "Kamusal Hizmet" daha uygun olmasına rağmen "Kamu Hizmeti" tabirinin söyleniş açısından kolay olması onun daha çok tutunmasına ve kullanılmasına sebebiyet vermiştir (Derbil, 1950).

$\mathrm{Bu}$ tarihsel geçmişe rağmen Türkiye'de kamu hizmeti kavramı yasalarda, yargı kararlarında çeşitli hukuk dallarında ve özellikle idare hukukunun en temel ve yaygin kullanilan kavramlarından biri olmasina rağmen üzerinde uzlaşılan herhangi bir tanımlamaya sahip olamamıştır. Bunu çeşitli yazarların tanımlamalarında da görmek mümkündür. Sözgelimi Gözübüyük ve Tan (2007)' a göre “Kamu Hizmeti “Toplumun ortak bazı gereksinimlerini karşılamak amacıyla doğrudan ve yakın gözetimi ve sorumluluğu altında, kamusal yetki ve usuller kullanarak yürüttüğü faaliyetlerdir ve kamu hizmeti kavramının organik unsur, maddi unsur ve biçimsel unsur/hukuksal rejim olarak üç unsur ile ayırt edilebileceğini belirtmektedirler.

Buna karşın Duran (1982) ise Kamu hizmetini; " Kamu hizmetleri devletin veya diğer kamu tüzel kişilerinin toplumun halkın veya umumun ya da toplulukların genel ortak ihtiyaçlarını gereği gibi karşılamak amaciyla ele alıp doğrudan, doğruya ifa ettiği, ya da buyruğu ve sorumluluğu altında başkalarına yaptırdığı her türlü faaliyetler" olarak tanımlamıştır. Görüldüğü gibi Türkiye'de kamu hizmeti kavramı doğuşundan günümüzdeki hukukçulara kadar kamu hizmeti ile ilgili çeşitli tanımlamalar ortaya çıkmaktadır. Bunun nedeni de kamu hizmetinin sürekli değişmesi, gelişmesi ve çeşitlenmesidir. Bu nedenle kamu 
hizmetinin salt belirli bir çerçeveden tanımını yapmak kamu hizmetini tam olarak anlaşılmasının önünde engel oluşturabilme ihtimali vardır. Ancak yapılan bütün tanımlamalarda ortaya konulan ve kamu hizmeti kavramına özgü olan bazı unsurların olduğu göze çarpmaktadır. Bu açıdan kamu hizmetini sahip olduğu unsurlar açısından açıklamak daha doğru olacaktır. Buna göre yapılan bir faaliyetin kamu hizmeti sayılabilmesi için ilk olarak faaliyetin bir kamu tüzel kişisi tarafından yerine getirilmesi gerekmektedir. İkinci olarak, faaliyetin kamu yararı amacı olması yani faaliyetin mahiyetinin kamu hizmeti taşımasıdır. Son olarak ise kamusal yetki ve usuller çerçevesinde faaliyetin yerine getirilmesi gerekmektedir. Bu bağlamda, kamu hizmetinin sahip olduğu unsurların belirlenmesinde hakim olan temel anlayışlar mevcuttur. Bu anlayışlar objektif kamu hizmeti ile sübjektif kamu hizmeti olmak üzere ikiye ayrılmaktadır.

\section{Objektif Kamu Hizmeti}

Bazı faaliyetlerin özellikleri gereği kamu hizmeti olduğunu ve yönetimin kamu hizmetini belirlemeyeceğini savunur (Ulusoy, 1999). Bu yaklaşımın kurucusu ve aynı zamanda en önemli temsilcisi olan Duguit'e göre kamu hizmeti; karşılıklı toplumsal bağımlılığın gerçekleşmesi ve gelişmesi için kaçınılmaz ve niteliği gereği tam olarak gerçekleştirilebilmesi ancak yönetici gücün devreye girmesiyle mümkün olması nedeniyle yönetenlerce sağlanması, düzenlenmesi ve denetlenmesi gereken faaliyetlerdir (Karahanoğulları, 2004). Duguit'in anlayışında, kamu hizmeti devletin kurucu unsurlarından birisidir. Duguit, ülke ile birlikte kamu hizmetini de devletin kurucu unsurları arasında saymakta; egemenliği ve kamu gücünü devletin kurucu unsurları arasından çıkararak bunların yerine kamu hizmetini koymaktadır (Orak, 2007).

\section{Sübjektif Kamu Hizmeti Anlayışı}

Objektivist kamu hizmeti anlayışında olduğu gibi, durağan (dogmatik) bir anlayış yerine, göreceli/değişken bir kamu hizmetini benimsemekte ve maddi bir belirleme yapmayıp, şekli bir ölçüt kullanarak yetkili otoritenin kamu hizmeti olarak kabul ettiği hizmetleri kamu hizmeti olarak tanımla- 
maktadır (Ulusoy, 2004). Sübjektivist görüş kamu hizmetlerini, yasa koyucu tarafindan kamu hizmeti olarak kabul edilen faaliyetleri kamu hizmeti saymaktadır. Sübjektivist anlayışın öne çıkan özelliği özneyi vurgulamasıdır (Karahanoğulları, 2004). Sübjektif kamu hizmeti anlayışına yöneltilen en önemli eleştiri ise, yetkili otoritenin yeterince açık olmadığı durumlarda, bir faaliyetin kamu hizmeti sayılıp sayılamayacağının da o oranda tatmin edici biçimde ortaya konulamayacağıdır (Orak, 2007).

Hizmet faaliyetinin etkinliğinin göz önüne alınmasındaki amaç özel kişilere ait olmasına rağmen bazı faaliyetlerin kamu hizmeti sayılmasıdır. Bir kamu tüzel kişisi tarafından doğrudan doğruya veya bir kamu tüzel kişisinin denetimi altında bir özel hukuk kişisi tarafından yürütülen faaliyetin kamu hizmeti olarak nitelendirilebilmesi için söz konusu faaliyetin kamu yararı amacını gerçekleştirmeye yönelik bir faaliyet olması gerekmektedir (Orak, 2007). Günümüzde ise hangi faaliyetin kamu yararı içerdiği oldukça belirsizdir. Ayrıca kamu hizmeti olarak kabul edilen bazı faaliyetlerin de kamu yararı ile doğrudan bağı olmadığı görülmektedir. Kamu hizmeti, geleneksel olarak, sorumluluğu bir kamu tüzel kişisi tarafından üstlenilen (organik unsur) ve kamu yararı içeren (maddi unsur) ve bu yönüyle, kamu hukuku rejimine tabi tutulan bir faaliyet olarak karşımıza çıkmaktadır (Ulusoy, 2004).

\section{Kamusal Mal ve Hizmetlerin Sinıflandırılması}

İnsanların bir arada yaşamalarından kaynaklanan bir takım ihtiyaçları vardır ki bu ihtiyaçlar toplumsal ihtiyaçlar olarak adlandırılır. Toplumun en üst örgütlenme şekli olan devletin temel varlık sebebi, söz konusu kamusal nitelikli ihtiyaçların karşılanmasıdır. Bu ihtiyaçları karşılamak için devlet tarafından üretilmesi zorunlu olan mal ve hizmetler, "kamusal mal ve hizmetler" olarak tanımlanır. Diğer bir anlatımla, Kamusal hizmetler ya da mallar, devletçe yerine getirilmesi gereken ihtiyaçlardır. Bunlar saf kamusal hizmetler ve yarı kamusal hizmetler olmak üzere ikiye ayrılmaktadır. Saf kamusal ihtiyaçlar yapıları gereği karşılanması piyasa mekanizmasına bırakılmayan ihtiyaçlardır. Saf kamusal ihtiyaçlar arasında ulusal savunma, adalet gibi ihtiyaçlar girmektedir. Aynı za- 
manda bu hizmetler kamu kesimini ortaya çıkaran temel unsur olduğundan, saf ihtiyaçlardan bireyleri mahrum etmek çok zor ve maliyetlidir. Fakat eğitim, sağlık gibi saf olmayan kamusal ihtiyaçların aşırı tüketiminin olması ve maliyetinin karşılanmasının zor olması, bu gibi malların karşılanması dışsallıkları nedeniyle kamunun düzenleyiciliğiyle piyasa mekanizmasına bırakılabilmektedir (Çelebi ve Diğ., 2008).

\section{Kamu Hizmetinde Değişim ve Yeni Kamu Hizmeti Anlayışı}

Günümüz modern toplumunda halkın gereksinim duyduğu kamu hizmetlerini etkin ve kaliteli bir şekilde karşılamak modern devletin en önemli görevlerinden biri olarak görünmektedir. İnsanların artan ihtiyaçları ile hızla değişen ve gelişen toplum yapısı klasik yönetim anlayışının ve onun sunduğu kamu hizmetinin sorgulamasına neden olmuştur. Geleneksel kamu yönetimi anlayışından yeni kamu yönetimi anlayışına geçişte olduğu gibi geleneksel kamu hizmetlerinden yeni kamu hizmeti anlayışına geçişinde bir takım nedenleri mevcuttur. Halkın gerek duyduğu kamu hizmetlerini etkin ve kaliteli bir şekilde sunmak için kamu yönetim anlayışında da gerekli değişim ve dönüşüm hareketleri başlamıştır.

Geleneksel kamu yönetimi anlayışının yerini yeni kamu yönetimi (New Public Management) anlayışına bırakması ve yeni kamu yönetimi anlayışının, işletme yönetiminin benimsemiş olduğu bir takım prensipleri benimsemiş olması kamu hizmetlerinin daha hızlı ve müşteri odaklı olarak sunumunu sağlamıştır (Sezer, 2008). Özellikle batılı ülkelerde ortaya çıkan ve benimsenen "Yeni Kamu Hizmeti" anlayışı yeni kamu yönetiminin ilkelerini hizmet sunumunda kullanmaktadır. Bu anlayış kamu hizmeti ile ilgili bazı yeni yöntem ve uygulamalar benimseyerek gelişimini devam ettirmektedir. Yeni kamu hizmeti anlayışının kullandığı yöntem ve uygulamaları Denhardt ve Denhardt (2002) şu şekilde ifade etmiştir;

- Doğrudan hizmet etmek yerine yönlendirmek. Kamu çalışanının giderek önemi artan bir rolü toplumu yeni yönlere doğru yönlendirmeye veya kontrol etmeye çalışmaktan ziyade vatandaşların ortak menfaatlerini açıkça anlamaları ve tanımalarına yardımcı olmaktır. 
- Kamu yararı amaçtır (hedef), yan ürün değildir. Kamu yöneticileri ortak paylaşılan bir kamu yararı eğilimi oluşturmaya katkıda bulunmalıdır. Amaç kişisel tercihlere dayalı çabuk çözümler bulmak değildir. Burada amaç paylaşılan menfaatler ve sorumluluk oluşturmaktır.

- Stratejik düşün demokratik hareket et. Kamu ihtiyaçlarını karşılayan politikalar ve programlar en etkin ve güvenilir şekilde ortak çabalar ve işbirlikçi süreçler aracılığıyla elde edilir.

- Vatandaşlara hizmet edin müşterilere değil. Kamu yararı kişilerin şahsi çıkarlarının toplamından çok paylaşılan (ortak) değerlerin sonucudur. Bu nedenle kamu çalışanları sadece müşterilerin taleplerine cevap vermekle kalmaz bunun yanında vatandaşlarla ve vatandaşlar arasında güven ve işbirliği ilişkilerinin oluşturulmasına yoğunlaşır.

Kamuda faaliyet gösteren kuruluşlar, sadece müşterilerinin tatminini gerçekleştirmeyi değil, onlardan hem müşteri beklentilerini hem de müşteri açısından hizmet algılarını da öğrenmek zorundadır (Wisniewski ve Donnelly, 1996; Yüzgenç, 2010).

\section{Günümüzde Kamu Hizmetinde Kalite}

Kalite kavramı günümüz toplumlarının ve toplumsal kurumlarının en önemli sloganı haline gelen kavramlarından birisidir. Küreselleşme süreci, devletin küçültülmesini beraberinde getirirken, yönetimdeki yeni anlayışlar, halkın devletten beklentilerini de bir ölçüde arttırmıştır. Günümüzde devletten beklenen hizmetlerin kaliteli olması istenmektedir. Kamu sektöründe özelleştirme ve yerel yönetimlere yetki devriyle birlikte halkın daha kaliteli hizmet sunumu bekleme talepleri de artmış bulunmaktadır (Sezer, 2008). Kamu hizmeti kavramının değişim dönüşüm ve nihayetinde geldiği noktada sahip olduğu kalite önem taşımaktadır. Genel olarak günümüzde olması gereken kalite boyutları konuyla ilgilenen bilimsel çevrelerde şöyle kabul edilmektedir (Usta ve Memiş, 2010, İnce ve Şahin, 2014):

Somut Özellikler: Binaların Kullanılan teçhizatın, iletişim malzemelerinin ve personelin görünümü, 
Güvenilirlik: Vaat edilen hizmeti doğru olarak yerine getirme yeteneği,

Heveslilik: müşterilere/vatandaşlara yardım etme ve hızlı hizmet verme istekliliğ $\mathrm{i}$,

Yeterlilik: Hizmeti yerine getirmek için gereken bilgi ve yeteneğe sahip olunmas1,

Nezaket: Müşteri/vatandaş ile doğrudan ilişki kuran personelin nazik, saygıll, düşünceli ve samimi olması,

İnanılabilirlik: Hizmeti sunan kişinin güvenilir ve dürüst olması,

Güven: Çalışanların bilgili ve nazik olmaları ve müşterilere güven duygusu uyandırabilme becelerileri,

Erişim: Gerektiğinde iletişim kurma kolaylığı ve erişilebilirlik,

İletişim: Anlayabileceği dilden müşterinin/vatandaşın bilgilendirilmesi ve sorunlarının dinlenmesi,

Empati: Çalışanların kendilerini müşterilerin/vatandaşların yerine koyması ve müşterilere kişisel ilgi göstermesidir.

Yukarıda belirtilen bu boyutları bağlamında hizmet kalitesi, vatandaşların hizmeti aldıktan sonra o hizmettin kendilerinde yarattığ1 duygu olup, söz konusu hizmetten ne kadar tatmin olup olmadığının ifade edilmesidir (Çiçek ve Doğan, 2009).

Belediyelerin sunduğu hizmet kalitesini ölçen, hizmetten yararlanan vatandaşlardır. Beklentiler doğrultusunda hizmet kalitesi bireyden bireye farklılık göstermektedir. Beklentileri kişinin sahip olduğu eğitim seviyesi, gelir durumu ve sosyal düzeyi gibi pek çok değişken etkilemektedir. Bu çalışmanın temel amacı, bu değişkenlere bağlı olarak Belediyelerin sunduğu kamu hizmetlerini genç bireylerin nasıl algıladıkları ve hizmet memnuniyet düzeyini belirleyen yukarıdaki teorik temel faktörler dikkate alınarak neler olduğunu ortaya koymaya çalışmaktır. 


\section{Materyal ve Metot}

$\mathrm{Bu}$ araştırmayla büyükşehir belediyelerin sunduğu tüm hizmetlerin söz konusu hizmeti alan genç bireyler bakımından algılanan ve beklenen hizmet kalitesi algılarını tespit edilerek gençlerin hizmet kalitesi algı düzeylerini belirlemek ve yeni yapılması düşünülen hizmetlere katkı sağlamaya çalışmaktır.

\section{Araştırmanın Amacı, Modeli, Kapsamı-Sınırlılıkları, Hedef Kütlesi}

Büyükşehir belediyesine kapsamında yaşayan gençlerin kamu hizmeti algısını, nasıl bir kamu görevlisi istediklerini ve kamu görevlilerinden nasıl bir hizmet beklediklerini tespit etmeyi amaçlamıştır. Araştırmanın kapsam ve sınırlılığını büyükşehir belediyesi kapsamında yaşayan farklı Sosyo-Kültürel ve Sosyo-Ekonomik bireyler oluşturmaktadır. Özellikle, bu bireylerin 15-39 yaş grubundaki kişiler olmasına dikkat edilmiştir. 1539 yaş grubunun seçilmesinin nedeni, Türkiye'deki yaş ortalamasının yükselmesi ile lisans sonrası eğitimin (yüksek lisans ve doktora) yaygınlaşmasıdır. Araştırmanın ana kütlesi yeni Büyükşehir Belediyesi olmuş kentlerde ikamet eden farklı sosyo-kültürel ve sosyo-ekonomik özellikteki genç bireylere maliyet, zaman, işgücü, doğruluk, ayrıntılı bilgi, birimlerin kendini kaybetmesi ve birimlerin tamamına ulaşamama gibi nedenlerle örnekleme yapılması zorunlu görülmüştür. Bu evren içerisinden doğru bir örneklem seçebilmek için öncelikle örnekleme çerçevesi belirlenmiştir. Bu çerçeve kent merkezine bağlı mahalle ve beldelerde ikamet eden bireylerden oluşmaktadır. Bu mahallenin seçilme nedeni genç yurttaşların Sosyo- Ekonomik ve sosyo kültürel özeliklerini en iyi temsil eden bölge olduğu varsayımıdır.

Örnekleme dâhil edilecek olan denekler büyükşehirde ikamet eden 1539 yaş grubunda yer alanlar arasında kolayda örnekleme metodu kullanılarak seçilmiştir. Kolay (Kolayda) örnekleme yöntemi en kolay bulunan denek en ideal olanıdır prensibinden hareketle, örneklem büyüklüğüne ulaşılıncaya kadar arzu eden herkesin örnekleme alındığı yöntemdir. Örnekleme yöntemi olarak tesadüfi (rassal-olasıklı) tabakalı (Zümrelere göre) örnekleme metodu tercih edilmiştir. Tabakalı örnekleme yöntemi; incelenen özelik açısından heterojen yapıdaki ana kütlelerin 
homojen alt gruplara (tabakalara) ayrıldığ 1 ve bu tabakalardan tespit edilen sayılarda tesadüfi olarak birimlerin seçildiği örneklemedir. Örneklemin Ana kütleyi iyi temsil yeterliliğine sahip bir hedef kütle (örneklem) seçilmiştir. \%6 de 266, \%7 de 196 ve \%10 da 96 kesinlik seviyelerinde (Güvenirlik seviyesi \%95 ve p=0.5) 240-270 kişilik bir örneklem sayısı belirlenmiştir. Bu sayının evreni temsil edileceği varsayılmaktadır. Hata payı hesabı olarak; güven düzeyi \%95 değerinde örneklem büyüklüğü 243 katılımcıda hata payı da bu orandadır.

\section{Ölçme Aracı ve Veri Toplama Yöntemi}

Ölçme, gözlenen gözlenmiş bir olgu, olay veya durumun belirli kurallar çercevesinde rakamsal olarak yazılıp tasnif ve değerlendirilmesi işlemidir. Birey ya da nesnelerin sahip oldukları özelliklerin açıklanması dört ayrı ölçek türü ile yapılmaktadır. Araştırma da ise özellikle sosyal bilimlerde psikoloji ve eğitim alanlarında kullanılan ve aralık ölçeği olarak kabul edilen likert tipi ölçek kullanılmıştır. Likert türü ölçek, çoğunlukla bir orta (yansız) noktası ve iki pozitif ve iki negatif kademesi olan 5 seçenekli bir ölçektir. Gençlerinin Büyükşehir Belediye Hizmet Algısı ve Beklentilerinin ölçülmesi analizi için gerekli veriler anket yöntemiyle yüz yüze yapılarak toplanmış ve anket dört bölümden oluşmaktadır.

İlk bölümde katılımcıların demografik özeliklerini belirlemeyi ve onları tanımayı amaçlayan sorular yer almıştır. Anketin ikinci bölümünde ise, gençlerin büyükşehir belediyesinin hizmetleri ve çalışanları hakkında sahip olduğu tutum ve davranışları ölçmeyi amaçlayan sorulara yer almaktadır. Diğer bir anlatışla, gençlerin yaşadıkları yerlerin yerel yönetimlerinde çalışan kamu görevlilerinin tutum ve davranışlarını nasıl değerlendirdikleri belirlenmek istenmiştir. Anketin üçüncü bölümünde ise, gençlerin yaşadıkları büyükşehir belediyesinin hizmet performanslarını ve etik değerlere ne derece riayet ettiği hakkındaki algılamasını ölçemeye yönelik sorular yer almaktadır. Burada güdülen amaç, gençlerin performans ve etik değerlere ne derece önem verdiklerini öğrenmektedir. Ayrıca Büyükşehir belediyelerinin de performans ve etik değerlere riayet etmesinin önemini göstermektedir. Son bölümde ise, gençlerin yaşadıkları yerlerdeki yerel yönetimlerden beklentilerini öğrenmeye yönelik sorular yer almaktadır. Burada güdülen amaç ise, yerel 
yönetimlerin gençlere yönelik hizmetlerini yeniden değerlendirmesini sağlamak ve gençlerin geleceğe daha umutlu bakmasını sağlayacak tedbirler almayı sağlamaktır.

Ölçmek için veri edinme tekniklerinden anket yöntemiyle gençlerin bireylerin büyükşehir belediye hizmet algısı ve beklentilerini ölçmek amacıyla "Demografik Değişkenler" (4 soru), "Tutum ve Davranış Algısı" (10 soru), "Performans ve Etik Değer Algisı" (6 soru) ve "Beklentiler Algısı" na (10 soru) yönelik toplam 30 maddeden oluşan bir anket formu oluşturulmuş ve uygulanmıştır. Söz konusu anket ölçek soruları bu alanda yapılan çalışmalardan esinlenerek yeniden geliştirilmiştir. Anketteki sorular 5'li likert tipi biçiminde hazırlanıp uygulanmıştır. Soruların ölçeklendirmesinde "1=Kesinlikle Katılmıyorum 2=Katılmıyorum 3=Kararsızım 4= Katılıyorum 5= Kesinlikle Katılıyorum" biçiminde ifade edilmiştir.

\section{Bulgular}

Elde edilen veriler tablolar halinde aşağıda sunulmuştur.

Tablo 1. Demografik Değişkenler Analizi

\begin{tabular}{|r|c|c|}
\hline & Frekans (n) & Yüzde (\%) \\
\hline Cinsiyetiniz? & & 37 \\
\hline Kadın & 90 & 63 \\
\hline Erkek & 153 & 45 \\
\hline 15-20 arası & 110 & 49 \\
\hline $21-29$ aras1 & 118 & 6 \\
\hline 30 ve üzeri & 15 & 4 \\
\hline Eğitim Durumunuz? & & 90 \\
\hline Ilköğretim-Lise & 10 & 6 \\
\hline Üniversite & 218 & 39 \\
\hline Yüksek Lisans-Doktora & 15 & 27 \\
\hline Gelir durumunuz? & & 11 \\
\hline 0-500 TL aras1 & 95 & 23 \\
\hline 501-1000TL aras1 & 65 & $\mathbf{1 0 0}$ \\
\hline 1001-1500 TL aras1 & 27 & \\
\hline 1501 ve üzeri & 56 & \\
\hline Toplam & $\mathbf{2 4 3}$ & \\
\hline
\end{tabular}

Tablo 1. incelendiğinde; araştırmaya katılanların büyük bir çoğunluğunun erkek olduğu (n=153, \%63), yaş aralığ olarak $15-20$ yaş arası ile 
21-29 yaş arası olanların oranı yaklaşık aynı olduğu ( $n=228, \% 94)$, çoğunluğun üniversite eğitim düzeyinde olduğu $(n=218, \% 90)$, gelir durumu olarakta 0-500tl arası olanların çoğunlukta olduğu (n=95, \%39), 501-1000tl arası ile $(n=65, \% 27) 1501$ ve üzeri olanların $(n=56, \% 23)$ aynı olduğu görülmektedir.

Tablo 2. Tutum ve Davranış Algısına Yönelik Frekans Değerleri Tablosu

\begin{tabular}{|c|c|c|c|c|c|c|c|c|c|c|}
\hline \multirow[t]{2}{*}{$\begin{array}{l}\text { Tutum ve Davranış Algısı } \\
\text { Değişkenleri }\end{array}$} & \multicolumn{2}{|c|}{ 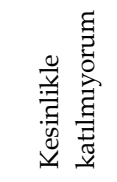 } & \multicolumn{2}{|c|}{ 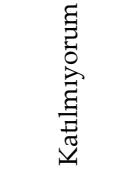 } & \multicolumn{2}{|c|}{ 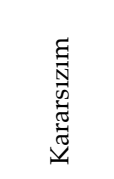 } & \multicolumn{2}{|c|}{ 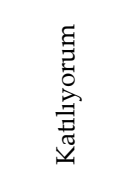 } & \multicolumn{2}{|c|}{ 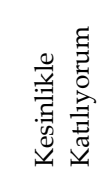 } \\
\hline & $f$ & $\%$ & $\mathrm{f}$ & $\%$ & $\mathrm{f}$ & $\%$ & $f$ & $\%$ & $f$ & $\%$ \\
\hline $\begin{array}{l}\text { 1. Belediye görevlisinin zihnimde } \\
\text { olumlu bir izlenim meydana } \\
\text { getirdiğini düşünüyorum. }\end{array}$ & 25 & 10 & 29 & 12 & 98 & 41 & 66 & 27 & 25 & 10 \\
\hline $\begin{array}{l}\text { 2. Belediye görevlisinin kendini } \\
\text { halktan üstün gördüğünü } \\
\text { düşünüyorum. }\end{array}$ & 65 & 27 & 81 & 33 & 44 & 18 & 46 & 19 & 7 & 3 \\
\hline $\begin{array}{l}\text { 3. Belediye görevlilerinin aldıkları } \\
\text { maaşı hak ettiklerini düşünüyorum. }\end{array}$ & 19 & 8 & 35 & 15 & 81 & 33 & 74 & 30 & 34 & 14 \\
\hline $\begin{array}{l}\text { 4. Büyükşehir belediyesine karşı ön } \\
\text { yargı olduğunu düşünüyorum. }\end{array}$ & 43 & 18 & 64 & 26 & 78 & 32 & 39 & 16 & 19 & 8 \\
\hline $\begin{array}{l}\text { 5. Büyükşehir Belediyesinde gerek- } \\
\text { tiğinde yöneticilere kolay ulaşabili- } \\
\text { yorum. }\end{array}$ & 54 & 22 & 56 & 23 & 83 & 34 & 39 & 16 & 11 & 5 \\
\hline $\begin{array}{l}\text { 6. Kamu hizmeti alırken belediye } \\
\text { görevlilerinin kötü muamelesine } \\
\text { uğradığımı düşünüyorum. }\end{array}$ & 73 & 30 & 87 & 36 & 40 & 16 & 26 & 11 & 17 & 7 \\
\hline $\begin{array}{l}\text { 7. Belediye görevlileri, hizmet } \\
\text { sunarken vatandaşa yeterince za- } \\
\text { man ayırdıklarını düşünüyorum. }\end{array}$ & 27 & 11 & 51 & 21 & 95 & 39 & 57 & 24 & 13 & 5 \\
\hline $\begin{array}{l}\text { 8. Büyükşehir Belediyesinden hizmet } \\
\text { alırken yöneticilerin eşitlik ve } \\
\text { tarafsızlık ilkelerini dikkate aldığını } \\
\text { düşünüyorum. }\end{array}$ & 40 & 16 & 38 & 15 & 97 & 40 & 52 & 21 & 16 & 7 \\
\hline $\begin{array}{l}\text { 9. Belediye görevlilerinin yanlış tu- } \\
\text { tumları ve davranışları Belediyeye } \\
\text { olan güvenimi sarstığını } \\
\text { düşünüyorum. }\end{array}$ & 16 & 6 & 41 & 17 & 67 & 27 & 73 & 31 & 46 & 19 \\
\hline 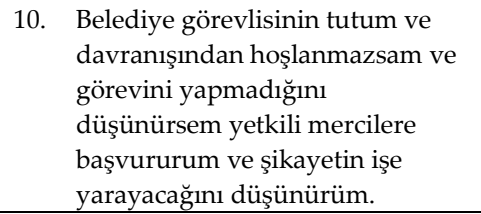 & 39 & 16 & 49 & 20 & 57 & 23 & 58 & 24 & 40 & 17 \\
\hline
\end{tabular}


Katılımciların tutum ve davranış algısına yönelik Tablo 2 incelendiğinde; katılımcılar, belediye görevlisinin zihninde olumlu bir izlenim meydana getirdiğini düşünme konusunda \%41'i kararsız kaldığını ve \%37'sinde olumlu izlenim meydana getirdiğini; \%60'1 belediye görevlisini halktan üstün görmediğini, \%44'ü aldıkları maaşı hak ettiklerini ve belediyeye karşı önyargı beslediklerini, \%45'i gerektiğinde ilgili yöneticilere kolay ulaşamadığını, \%66'sı hizmet alırken görevlilerin kötü muamelesine uğradığını, \%40'1 görevlilerin hizmet sunarken bireylere yeterince zaman ayırmadığını düşünme ile eşitlik ve tarafsızlık ilkelerini dikkate alma konusunda kararsız kaldığını, \%50'si yanlış tutum ve davranışların belediyeye olan güvenini sarstığını ayrıca tutum ve davranışından hoşlanmadığı takdirde görevini yerine getirmediğini düşündüğünde yetkili kişilere şikayetin işe yarayacağı konusunda eşit bir dağılım gösterdiği bulgularımız arasındadır.

Tablo 3. Performans ve Etik Değer Algısına Yönelik Frekans Değerleri Tablosu

\begin{tabular}{|c|c|c|c|c|c|c|c|c|c|c|}
\hline \multirow[t]{2}{*}{$\begin{array}{l}\text { Performans ve Etik Değer Algısı } \\
\text { Değişkenleri }\end{array}$} & \multicolumn{2}{|c|}{ 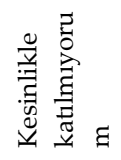 } & \multicolumn{2}{|c|}{ ᄅ્ટّ } & \multicolumn{2}{|c|}{ 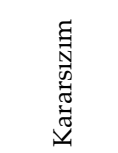 } & \multicolumn{2}{|c|}{$\underset{\Xi}{\stackrel{\Xi}{\Xi}}$} & \multicolumn{2}{|c|}{ 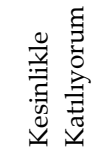 } \\
\hline & $\mathrm{f}$ & $\%$ & f & $\%$ & f & $\%$ & f & $\%$ & f & $\%$ \\
\hline $\begin{array}{l}\text { 1. Belediye görevlileri hizmet sunarken } \\
\text { etkin, verimli ve tutumludurlar. }\end{array}$ & 15 & 6 & 41 & 17 & 108 & 44 & 65 & 27 & 14 & 6 \\
\hline $\begin{array}{l}\text { 2. Belediye görevlisi işini yaparken } \\
\text { özverili ve hızlı çalışarak vatandaşı } \\
\text { fazla bekletmemektedirler. }\end{array}$ & 29 & 12 & 61 & 25 & 81 & 33 & 62 & 26 & 10 & 4 \\
\hline $\begin{array}{l}\text { 3. Belediye görevlilerinin kaliteli hiz- } \\
\text { met sunduklarını düşünüyorum. }\end{array}$ & 23 & 9 & 51 & 21 & 94 & 39 & 60 & 25 & 15 & 6 \\
\hline $\begin{array}{l}\text { 4. } \\
\text { Belediye de görevli kişilerin çok hızlı } \\
\text { çalıştıklarından kuyruk sırası } \\
\text { oluşmadığını ve vatandaşa hemen } \\
\text { sıranın geldiğini düşünüyorum. }\end{array}$ & 42 & 17 & 55 & 23 & 84 & 35 & 44 & 18 & 18 & 7 \\
\hline $\begin{array}{l}\text { 5. } \\
\text { Belediye görevlileri kamu kaynak- } \\
\text { larını kullanırken çok savurgan dav- } \\
\text { ranmaktadırlar. }\end{array}$ & 12 & 5 & 54 & 22 & 110 & 45 & 40 & 17 & 27 & 11 \\
\hline $\begin{array}{l}\text { 6. } \\
\text { larını tasarruflu ve israf etmeden } \\
\text { kullanmaktadırlar. }\end{array}$ & 25 & 10 & 46 & 19 & 106 & 44 & 50 & 21 & 16 & 6 \\
\hline
\end{tabular}


Katılımcıların performans ve etik değer algısı bakımından Tablo 3 incelendiğinde; \%44'ü görevlilerin hizmet sunarken etkin, verimli ve tutumlu olduğu konusunda kararsız kaldığını, görevlinin işini yaparken özverili ve hızlı çalışarak bireyi fazla bekletmeme, kaliteli hizmet sunma konusunda eşit dağılım gösterdiği, kamu kaynaklarını kullanırken savurgan davranma ile kamu kaynaklarını tasarruflu ve israf etmeden kullanma bakımından tutarlı ve kısmen eşit bir dağılım gösterdiği kararsızların bu konuda yaklaşık \%45 olduğu bulgularımız arasındadır.

Tablo 4. Beklentiler Algısına Yönelik Frekans Değerleri Tablosu

\begin{tabular}{|c|c|c|c|c|c|c|c|c|c|c|}
\hline \multirow[t]{2}{*}{ Beklentiler Algısı Değişkenleri } & \multicolumn{2}{|c|}{ 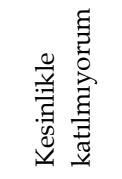 } & \multicolumn{2}{|c|}{ 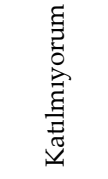 } & \multicolumn{2}{|c|}{ 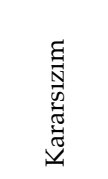 } & \multicolumn{2}{|c|}{ 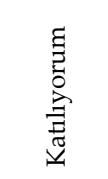 } & \multicolumn{2}{|c|}{ 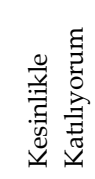 } \\
\hline & f & $\%$ & $\mathrm{f}$ & $\%$ & $\mathrm{f}$ & $\%$ & $\mathrm{f}$ & $\%$ & $\mathrm{f}$ & $\%$ \\
\hline $\begin{array}{l}\text { 1. Belediyenin ulaşım imkanları-saat- } \\
\text { leri düzenli ve yeterlidir. }\end{array}$ & 55 & 23 & 48 & 20 & 55 & 23 & 60 & 24 & 25 & 10 \\
\hline $\begin{array}{l}\text { 2. Belediyenin gençlere yönelik } \\
\text { Gençlik festivallerini yeterli bulu- } \\
\text { rum. }\end{array}$ & 48 & 20 & 53 & 22 & 57 & 23 & 64 & 26 & 21 & 9 \\
\hline $\begin{array}{l}\text { 3. Belediyenin peyzaj çalışmaları ve } \\
\text { yeşil park alanları yeterlidir. }\end{array}$ & 45 & 18 & 49 & 20 & 57 & 24 & 64 & 26 & 28 & 12 \\
\hline $\begin{array}{ll}\text { 4. } & \text { Belediyenin Ramazan Ayında iftar } \\
& \text { yemeği faaliyetleri yeterlidir. }\end{array}$ & 33 & 14 & 40 & 16 & 89 & 37 & 51 & 21 & 30 & 12 \\
\hline $\begin{array}{ll}\text { 5. } & \text { Belediyenin turizme yönelik } \\
\text { çalışmaları planlı ve yeterlidir. }\end{array}$ & 42 & 17 & 60 & 25 & 77 & 32 & 49 & 20 & 15 & 6 \\
\hline $\begin{array}{l}\text { 6. } \begin{array}{l}\text { Belediyenin ücretsiz (internet) wifi } \\
\text { ye yönelik hizmetleri yeterlidir. }\end{array} \\
\end{array}$ & 94 & 38 & 53 & 22 & 61 & 25 & 26 & 11 & 9 & 4 \\
\hline $\begin{array}{l}\text { 7. } \begin{array}{l}\text { Belediyenin konaklama (Ö̈̆renci } \\
\text { yurdu)-burs imkanları yeterlidir. }\end{array} \\
\end{array}$ & 103 & 42 & 50 & 21 & 53 & 22 & 35 & 14 & 2 & 1 \\
\hline $\begin{array}{ll}\text { 8. } & \text { Belediyenin ulaşım ücretleri makul } \\
\text { seviyededir. }\end{array}$ & 115 & 47 & 43 & 18 & 43 & 18 & 29 & 12 & 13 & 5 \\
\hline $\begin{array}{l}\text { 9. Belediyenin kültürel spor etkin- } \\
\text { likleri yeterlidir. }\end{array}$ & 58 & 24 & 54 & 22 & 71 & 29 & 41 & 17 & 19 & 8 \\
\hline $\begin{array}{l}\text { 10. 10. Belediyenin sokak hayvanlarına } \\
\text { yönelik çalışmaları yeterlidir. }\end{array}$ & 62 & 26 & 42 & 17 & 71 & 29 & 42 & 17 & 26 & 11 \\
\hline
\end{tabular}

Katılımcıların beklentiler algısı bakımından Tablo 4 incelendiğinde; ulaşım imkanları-saatleri düzenli ve yeterli seviyededir belirtenlerin eşit dağılım gösterdiği, \%44'ü gençlere yönelik yapılan gençlik festivallerinin 
yeterli olmadığını, peyzaj çalışmaları ve yeşil park alanları yeterlidir konusunda eşit dağılım gösterdiği, \%37'sinin ramazan ayında iftar yemeği faaliyetleri konusunda kararsız kaldığı, \%42'si turizme yönelik çalışmaları planlı ve yeterli olmadığını, \%60'1 ücretsiz internete (wi-fi) yönelik hizmetlerinin yetersiz olduğunu, \%63'ü konaklama (öğrenci yurdu) burs imkanlarının yetersiz az olduğunu, \%65'inin ulaşım ücretlerinin makul seviyede olmadığını, \%46'sının kültürel spor etkinlikleri ile sokak hayvanlarına yönelik çalışmaların yeterli olmadığı bulgularımız arasındadır.

\section{Sonuç ve Öneriler}

Günümüzde her alanda yaşanan hızlı değişim ve teknolojik gelişmeler yerel yönetimleri de bu eksende kaliteli etkin yenilikçi hizmet sunmaya yönlendirmiştir. Bu bakımından dünyada bütün ülkelerde yerel yönetim hizmetleri daha kaliteli ve müşteriye ya da bireylere daha hizlı sunulması için yeniden yapılandırılması kaçınılmaz olmuştur.

Yerel kamu hizmet yönetimlerinde bireylerin bekleyişlerine cevap verilmesi gerektiği, kurumun düşündüğünün ise her zaman doğru olmadığ birey beklentisine uygun olmadığı gerçeği karşımıza çıkmaktadır. Diğer yandan birey istek ve düşünceleri beklentileri zamana ve gelişmeye bağlı olarak süratle değişmektedir. Ulusal ve uluslararası alanda kamu yerel hizmetlerinde kalite ve beklentiyi iyileştirmeye yönelik büyük çaba ve gayretler sarf edilmektedir. Artık bireyin nazarında mal ve hizmetlerin kalitesi beklentisi ve zamanında yerine getirilmesi içerik ve sunumdan daha önemli hale gelmiştir.

Yerel yönetimler, özellikle de Büyükşehir Belediyeleri sosyal faaliyetler konusunda halkın memnuniyetini ön planda tutarak, spor tesislerinde hizmet kalitesini artırmak, var olan katılımcı sayısını artırmak ve aynı zamanda yeni katılımcı kazanmak için gerekli ve yeterli çabayı göstermelidir. Bu bağlı olarak değişen şartlara ayak uydurarak geçmiş kültür ve bağlarından kopmadan bireylerin istek ve beklentilerini en iyi şekilde karşılamaya çalışmalıdır.

Kamu kurum ve kuruluşlarında daha kaliteli hizmet sunulabilmesi için çeşitli performans standartlarının önceden tespit edilerek farklı yerlerdeki faaliyetleri daha da geliştirerek uygulaması gerekmektedir. Devlet yöne- 
timinde bürokrasi ve dolaylı hantal yapının azaltılması şeffaf hesap verilebilirlik acısından ön koşuldur. Müşteri birey odaklı bir yönetim yapılanmasına geçişte en önemli unsur kamu görevlisi-birey arasındaki iletişim uzaklığının ve ast üst ilişkilerinin kurumsal yapıya dönüşmesi zorunlu bir gerekliliktir. Bunun için yerel yöneticiler tarafından bireyler aydınlatılmalı, belediye görevlileri bu noktada hizmet içi eğitimlerden geçirilerek değişen gelişen konjektürel yapıya adapte olmaları sağlanmalıdırlar. Buna bağlı olarak her şeyden önce ne kadar kanun düzenleme uygulama olursa olsun bir fikir zihniyet değişimi gerektiği ve yapılacak tüm uygulamalara herkesin inanması desteklemesi gerektiğidir.

\section{Kaynakça}

Çelebi, A., Yalçın, K. ve Zafer A., (2008). Kamusal mallar teorisinin değişimi: bölgesel kamusal mallar. Yönetim ve Ekonomi Dergisi, 15(2), 1-8.

Çiçek, R., ve Doğan İ.C., (2009). Müşteri memnuniyetinin artırılmasında hizmet kalitesinin ölçülmesine yönelik bir araştırma: Niğde ili örneği. Afyon Kocatepe Üniversitesi I.I. I.B.F. Dergisi, 11(I), 199-217.

Derbil, S., (1950). Kamu hizmeti nedir?.Ankara Üniversitesi Hukuk Fakültesi Dergisi, 7(7), 28-36.

Duran, L., (1982). İdare hukuku ders notları. İstanbul: Fakülteler Matbaası.

Gözübüyük, A. Şeref ve Tan, T., (2007). İdare hukuku genel esaslar Cilt I-II, Ankara: Turhan Kitabevi.

İnce, M., ve Şahin, K., (2014). Belediye hizmetlerinde vatandaş memnuniyeti ölçümü: Selçuklu belediyesi örneği. SÜ İ̈BF Sosyal ve Ekonomik Araştırmalar Dergisi, 21, 1-21.

Denhardt, V.J., ve Denhardt, R.B., (2002). The new public service. Public Administration Review Journel, 60(6), 549-559.

Karahanoğulları, O., (2004). Kamu hizmeti. Ankara: Turhan Kitabevi.

Orak, C.Ç., (2007). Kamu hizmeti: Tabula rasa Avrupa birliği sürecinde nasıl doldurulacak?. TBB Dergisi, 68, 161-240.

Sezer, Ö., (2008). Kamu hizmetlerinde müşteri (vatandaş) odaklılı: Türkiye'de kamu hizmeti anlayışı açısından bir değerlendirme. ZKÜ Sosyal Bilimler Dergisi, 4(8), 147-171.

Ulusoy, A., (2004). Kamu hizmeti incelemeleri. Ankara: Ülke Kitapları. 
Ulusoy, A., (1999). Fransız ve AB kamu hizmeti anlayışlarının Türk hukukuna etkisi. AÜHFD, 48(1-4), 165-176.

Yılmaz, D., (2008). Türk hukukunda kamu hizmeti kavramı ve kriterleri. Gazi Üniversitesi Hukuk Fakültesi Dergisi, 7(1-2), 1215-1234

Yüzgenç, A., (2010). Yerel yönetimlerin sunduğu spor hizmetlerinde hizmet kalitesi. Yayımlanmamış Yüksek Lisans Tezi, Gazi Üniversitesi, Sağlık Bilimleri Enstitüsü.

Wisniewski, M., ve Donnelly, M., (1996). Measuring service quality in the public sector: The potential for Servqual. Total Quality Management, 7(4), 357-365.

\section{Kaynakça Bilgisi / Citation Information}

Çolak, M., Yapıcı, İ., Çolak, N. ve Çetin T. (2018). Gençlerin büyükşehir belediye hizmet algisı ve beklentileri (Örnek bir uygulama). OPUS Uluslararası Toplum Araştırmaları Dergisi, 8(Gençlik Araştırmaları Özel Sayısi), 299-317. 